\title{
Effects of dietary symbiotic supplementation on growth performance and duodenum histology of Japanese quail (Coturnix coturnix Japonica) reared in different flooring systems
}

\author{
Isa Coskun ${ }^{1 *}$, Guray Erener ${ }^{2}$, Hayrettin Cayiroglu ${ }^{1}$, Aydin Altop ${ }^{2}$, Huseyin Cayan ${ }^{1}$, Ahmet Sahin ${ }^{1}$ \\ ${ }^{1}$ Ahi Evran University, Faculty of Agriculture, Department of Animal Science, Kirsehir, Turkey. \\ ${ }^{2}$ Ondokuz Mayis University, Faculty of Agriculture, Department of Animal Science, Samsun, Turkey.
}

\begin{abstract}
The objective of this study was to determine the effect of dietary symbiotic supplementation on the growth performance and duodenum histological parameters of quail reared in different flooring systems. A total of 160 mixed-sex healthy quail $(47 \pm 0.32 \mathrm{~g})$ aged 14 days were used in a $2 \times 2$ factorial experimental design with four replicates, each including five males and five females. Two flooring systems (wire floor as control and wood shavings bedding) and two dietary treatments (symbiotic supplementation and no supplementation) were tested. Birds were transferred to four-tier cages for the trial. Each kilogram of the commercial diet included $224 \mathrm{~g}$ crude protein and 3,080 kcal metabolizable energy. The experiment lasted 21 days. Daily weight gain and gastrointestinal tract weight were statistically higher in the wood shavings and wood shavings + symbiotic-supplemented groups than in control group. Villi length was higher in the wood shavings + symbiotic and symbioticsupplemented groups than in control and wood shavings groups. The wood shavings groups had longer villi than control group. Villi width was higher in wood shaving + symbiotic-supplemented groups compared with the other treatment groups. The litter system of wood shavings and symbiotic supplementation provide better growth performance to quail by developing their duodenum histomorphological parameters and digestive tract.
\end{abstract}

Key Words: feed additive, litter, poultry, probiotic

\section{Introduction}

The ban on antibiotics as a growth factor in the European Union has led researchers to focus on natural feed additives such as prebiotics, probiotics, and symbiotics in animal nutrition (Genc et al., 2006; Ayasan, 2013; Hamasalim, 2016). Symbiotics (a mixture of probiotics and prebiotics), in particular, have been used as an antimicrobial agent for gastrointestinal development to promote higher weight gains. Saccharomyces cerevisiae and its cell wall mannan oligosaccharides (MOS) and $\beta$-glucan are one such natural feed additive. Erener et al. (2001), Zhang et al. (2005), and Ozsoy and Yalcin (2011) reported that Saccharomyces cerevisiae contains equivalent amounts of protein, amino acids, and $\mathrm{B}$ vitamins as soybean.

Received: June 5, 2017

Accepted: July 13, 2017

*Corresponding author: isa.coskun@ahievran.edu.tr

http://dx.doi.org/10.1590/S1806-92902017001000002

How to cite: Coskun, I.; Erener, G.; Cayiroglu, H.; Altop, A.; Cayan, H. and Sahin, A. 2017. Effects of dietary symbiotic supplementation on growth performance and duodenum histology of Japanese quail (Coturnix coturnix Japonica) reared in different flooring systems. Revista Brasileira de Zootecnia 46(10):800-804.

Copyright (C) 2017 Sociedade Brasileira de Zootecnia. This is an Open Access article distributed under the terms of the Creative Commons Attribution License (http://creativecommons.org/licenses/by/4.0/), which permits unrestricted use, distribution, and reproduction in any medium, provided the original work is properly cited.
It has been further reported that Saccharomyces cerevisiae (Nikpiran et al., 2013), MOS, (Markovicva et al., 2009), and $\beta$-glucan (Zhang et al., 2005; 2008) increased broiler performance and served as alternatives to antibiotic growth factors. By contrast, Ceylan and Ciftci (2003), Karaoglu and Durdag (2005), and Morales-López et al. (2009) stated that Saccharomyces cerevisiae and MOS or a mixture of the two did not improve broiler performance, whereas Ozturk and Yildirim (2004) reported that the success of probiotics and prebiotics, or their mixture as a symbiotic, depends on genetic, environmental, and different stress conditions.

Bedding-type management has been identified as another contributing factor. Sekeroglu et al. (2013) mentioned that bedding type is an important factor in the performance, welfare, health, behavior, and yield quality of poultry. Similarly, Fouad et al. (2008) reported that animals reared on wood shavings bedding had a more active life and ate more feed. Animals allowed to sandbathe in litter material exhibited better welfare. Samli et al. (2010) submitted that broiler performance increased with the use of dietary symbiotics and wood shavings bedding and suggested that increased broiler performance and welfare could be achieved through sand baths in litter material.

The literature features many studies analyzing the effects of Saccharomyces cerevisiae, MOS, and $\beta$-glucan on 
poultry performance, although those analyzing a symbiotic mixture of the three are few in number. To the present date, the effects of dietary symbiotics on the growth performance and duodenum histology of quail reared on different flooring systems have not been tested. On this basis, the present study was conducted to determine the effects of flooring systems and symbiotic supplementation (a mixture of Saccharomyces cerevisiae, MOS, and $\beta$-glucan) on growth performance, development of internal organs, and duodenum histomorphological parameters of Japanese quail.

\section{Material and Methods}

This experiment was conducted in Kırşehir, Turkey $\left(39^{\circ} 8^{\prime} 45.8736^{\prime \prime} \mathrm{S}, 34^{\circ} 9^{\prime} 34.2000^{\prime \prime} \mathrm{W}\right)$. The practices and procedures for this experiment were reviewed and approved by the local Animal Ethics Committee (22.01.2015/9). One hundred and sixty mixed-sex quail aged 14 days were used in this study. The quail were distributed into experimental groups and their replicates at equal body weights. The experiment was arranged as a $2 \times 2$ factorial design. Two factors were used for flooring system (wire floor as control and wood shavings bedding) and supplementation (symbiotic or no supplementation). Experimental groups were as follows: wire floor as control; wire floor + symbiotic supplementation only; wood shavings only; and wood shavings + symbiotic supplementation. The symbiotic product was obtained from Global Nutritech Company (800 E, Leigh Street Richmond, VA 23219, USA), including $88 \mathrm{~g} / \mathrm{kg}$ MOS, $96 \mathrm{~g} / \mathrm{kg} \beta$-glucan, and $4 \times 10^{12} \mathrm{cfu} / \mathrm{kg}$ Saccharomyces cerevisiae. Each treatment group was composed of four replicates and each replicate contained 10 chicks (five females and five males). Chicks were randomly transferred to four-tier, battery-type cages. Wood shavings were placed on the plastic bag lining the cage. Battery cages were equipped with wire mesh, dropping trays, nipple drinkers, and trough feeders. All birds were fed ad libitum. A commercial diet was prepared according to recommendations of the National Research Council (NRC, 1994) (Table 1). Illumination was provided during the experiment. Room temperature was $30{ }^{\circ} \mathrm{C}$ at the beginning of the study and then gradually decreased to $26^{\circ} \mathrm{C}$ on day 21 of the trial. Body weight and feed intake were measured at 14, 21, 28, and 35 days of age. At 35 days of age, two birds were slaughtered (one female and one male per replicate) to determine the weights of internal organs (heart, liver, and gizzard) and proventriculus, gastrointestinal tract length (GITL), gastrointestinal tract weight (GITW), and duodenum histomorphology.
Duodenum samples were cut into $1-\mathrm{cm}$ pieces and placed into $10 \%$ formalin for histomorphological processing. Tissue sections were inserted into tissue cassettes. After the dehydration process, tissue sections were embedded in paraffin blocks, cut to $5-\mu$ thickness, and placed on a slide. Each sample of duodenum histomorphological tissue was prepared and stained with hematoxylin and eosin solution by using standard paraffin-embedding methods (Xu et al., 2003). After the embedding process, duodenum villi length and duodenum width were evaluated by using an image processing and analysis system (ZEN 2012 SP2) for Zeiss Primo Star HD Light Microscope.

The data were analyzed using the general linear models procedure of the Statistical Package for the Social Sciences Software (SPSS 15). Differences between group means were separated by Duncan's multiple range tests.

\section{Results}

At the end of the study, there was no mortality. Daily weight gain was statistically higher in wood shavings and wood shavings + symbiotic supplementation groups than in control group $(\mathrm{P}<0.05)$ (Table 2). Feed intake and feed conversion ratio were not affected by any treatment, but feed conversion ratio tended to improve in all treatment groups compared with control group.

Table 1 - Composition of the experimental diet

\begin{tabular}{|c|c|}
\hline Item & $\mathrm{g} / \mathrm{kg}$ as fed \\
\hline \multicolumn{2}{|l|}{ Feed ingredient } \\
\hline Maize & 440.0 \\
\hline Soybean meal (44CP) & 411.5 \\
\hline Meat and bone meal (45CP) & 40.0 \\
\hline Soybean oil & 65.0 \\
\hline Dicalcium phosphate & 25.0 \\
\hline L-lysine $\mathrm{HCl}$ & 7.0 \\
\hline DL-methionine & 3.5 \\
\hline Salt & 3.0 \\
\hline Vitamin premix $^{1}$ & 2.5 \\
\hline Mineral premix ${ }^{2}$ & 2.5 \\
\hline \multicolumn{2}{|l|}{ Analyzed nutrient composition } \\
\hline Metabolizable energy (kcal/kg) & 3080 \\
\hline Crude protein & 223.9 \\
\hline Crude fiber & 28.0 \\
\hline Crude fat & 85.0 \\
\hline Calcium & 76.0 \\
\hline Available phosphorus & 38.0 \\
\hline \multicolumn{2}{|c|}{$\begin{array}{l}\text { CP - crude protein. } \\
{ }^{1} \text { Premix provided per } \mathrm{kg} \text { of diet: vitamin A, } 12.000 \mathrm{IU} \text {; vitamin D3, } 2.400 \mathrm{IU} \text {; } \\
\text { vitamin E, } 30 \mathrm{mg} \text {; vitamin } \mathrm{K} 3,4 \mathrm{mg} \text {; vitamin B1, } 3 \mathrm{mg} \text {; vitamin B2, } 7 \mathrm{mg} \text {; vitamin } \\
\text { B6, } 5 \mathrm{mg} \text {; vitamin B12, } 15 \mu \mathrm{\mu g} \text {;iacin, } 25 \mathrm{mg} \text {. } \\
2 \text { Premix provided per kg of diet: Fe, } 80 \mathrm{mg} \text {; folic acid, } 1 \mathrm{mg} \text {; pantothenic acid, } \\
10 \mathrm{mg} \text {; biotin, } 45 \mathrm{mg} \text {; choline, } 125,000 \mathrm{mg} \text {; Cu, } 5 \mathrm{mg} \text {; Mn, } 80 \mathrm{mg} \text {; Zn, } 60 \mathrm{mg} \text {; } \\
\text { Se, } 150 \mu \mathrm{g} \text {. }\end{array}$} \\
\hline
\end{tabular}


Gastrointestinal tract (GIT) weight was higher in wood shavings + symbiotic supplementation and wood shavings groups than in control group $(\mathrm{P}<0.05)$ (Table 3$)$. Wood shavings had an important effect on GIT weight, but this variable was not affected by symbiotic supplementation or by the symbiotic supplementation $\times$ wood shavings interaction. Edible internal organs (heart, liver, and gizzard), proventriculus, and GIT length did not differ among groups.

Villi length was higher in wood shavings + symbiotic supplementation and wire floor + symbiotic supplementation groups than in control and wood shavings groups; the villi length of wood shavings group was also higher than that of control group $(\mathrm{P}<0.01)$. According to these results, the wood shaving litter system, symbiotic supplementation, and the simultaneous use of both have an important effect on villi length. Villi width was highest in wood shavings + symbiotic supplementation group as compared with the other groups $(\mathrm{P}<0.01)$; villi width in wood shavings and wire floor + symbiotic supplementation groups was also higher than in control group. The wood shaving litter system and symbiotic inclusion to quail feed had a very important effect on villi width $(\mathrm{P}<0.01)$, but this was not true for their combined use.

\section{Discussion}

The results of this study showed that the wood shaving system increased daily weight gain compared with control group, but symbiotic supplementation did not affect daily weight gain. The wood shaving litter system increased quail performance by increasing their duodenum villi length and GITW. Increased GITW and duodenum villi length and thickness are signs of better development of the digestive tract. However, no significant differences were observed between the treatment groups regarding feed intake and feed conversion ratio. The increase in body weight gain could be attributed to the increased digestion activity in the GIT. Gastrointestinal tract length, villi length, and villi thickness may have a role on increased digestion activity in the GIT. It has been reported that dietary supplementation of Saccharomyces cerevisiae and MOS improved broiler performance, increased villi length/thickness ratio of both ileum and jejunum, and strengthened the digestive system (Baurhoo et al., 2009; Morales-López et al., 2009; Koc et al., 2010). In the current study, the higher daily weight gains and increased duodenum villi length and villi thickness with gastrointestinal weight may be due to the improvement of the animal welfare level in the wood shavings groups.

Table 2 - Effect of symbiotic supplementation and wood shaving system on quail performance parameters (g/day)

\begin{tabular}{|c|c|c|c|c|c|c|c|c|}
\hline \multirow{2}{*}{$\frac{\text { Wood shavings }}{\text { Symbiotic }}$} & \multicolumn{2}{|c|}{-} & \multicolumn{2}{|c|}{+} & \multicolumn{4}{|c|}{ P-value } \\
\hline & - & + & - & + & \multirow{2}{*}{ SEM } & \multirow{2}{*}{ W } & \multirow{2}{*}{$\mathrm{S}$} & \multirow{2}{*}{$\mathrm{W} \times \mathrm{S}$} \\
\hline Group & Control & $\mathrm{S}$ & W & $\mathrm{W}+\mathrm{S}$ & & & & \\
\hline DWG & $5.39 \mathrm{a}$ & $5.67 \mathrm{ab}$ & $6.00 \mathrm{~b}$ & $5.97 \mathrm{~b}$ & 0.10 & 0.02 & 0.75 & 0.63 \\
\hline FI & 18.97 & 19.47 & 19.89 & 19.23 & 0.19 & 0.30 & 0.98 & 0.10 \\
\hline FCR & 3.50 & 3.44 & 3.34 & 3.23 & 0.06 & 0.14 & 0.72 & 0.59 \\
\hline
\end{tabular}

$\mathrm{S}$ - symbiotic (Saccharomyces cerevisiae + MOS + $\beta$-glucan) only; W - wood shavings only; W+S - wood shavings and symbiotic inclusion; SEM - standard error of the mean; DWG - daily weight gain; FI - feed intake; FCR - feed conversion ratio.

$\mathrm{a}-\mathrm{b}$ - Means for the same treatment and effect or interaction effects with different letters differ significantly $(\mathrm{P} \leq 0.05)$.

Table 3 - Effect of symbiotic supplementation and wood shaving system on edible internal organs, gastrointestinal system development, and duodenum villi histology of quail chicks

\begin{tabular}{|c|c|c|c|c|c|c|c|c|}
\hline \multirow{3}{*}{$\begin{array}{l}\text { Wood shavings } \\
\text { Symbiotic } \\
\text { Group }\end{array}$} & \multicolumn{2}{|c|}{-} & \multicolumn{2}{|c|}{+} & \multicolumn{4}{|c|}{ P-value } \\
\hline & - & + & - & + & \multirow{2}{*}{ SEM } & \multirow{2}{*}{$\mathrm{W}$} & \multirow{2}{*}{$\mathrm{S}$} & \multirow{2}{*}{$\mathrm{W} \times \mathrm{S}$} \\
\hline & Control & $\mathrm{S}$ & W & $\mathrm{W}+\mathrm{S}$ & & & & \\
\hline $\mathrm{EIOW}^{1}(\mathrm{~g})$ & 6.16 & 6.15 & 6.27 & 6.57 & 0.07 & 0.08 & 0.31 & 0.26 \\
\hline Proventriculus $^{1}(\mathrm{~g})$ & 0.42 & 0.41 & 0.42 & 0.47 & 0.01 & 0.49 & 0.52 & 0.12 \\
\hline $\mathrm{GITL}^{2}(\mathrm{~cm})$ & 35.80 & 33.71 & 33.87 & 35.79 & 0.71 & 0.96 & 0.96 & 0.19 \\
\hline GITW $^{1}(\mathrm{~g})$ & $3.71 \mathrm{~b}$ & $4.10 \mathrm{ab}$ & $4.42 \mathrm{a}$ & $4.64 \mathrm{a}$ & 0.13 & 0.01 & 0.19 & 0.72 \\
\hline Villi length $(\mu)$ & $120.60 \mathrm{c}$ & $170.87 \mathrm{a}$ & $146.43 b$ & $178.34 \mathrm{a}$ & 2.88 & 0.001 & 0.001 & 0.002 \\
\hline Villi width $(\mu)$ & $11.03 \mathrm{c}$ & $13.07 \mathrm{~b}$ & $12.76 b$ & $15.78 \mathrm{a}$ & 0.34 & 0.001 & 0.001 & 0.39 \\
\hline
\end{tabular}

$\mathrm{S}$ - symbiotic (Saccharomyces cerevisiae + MOS + $\beta$-glucan) only; W - wood shavings only; W+S - wood shavings and symbiotic inclusion; SEM - standard error of the mean; EIOW - edible internal organs weight (heart + liver + gizzard); GITL - gastrointestinal tract length; GITW - gastrointestinal tract weight.

a-c - Means for the same treatment and effect or interaction effects with different letters differ significantly ( $\mathrm{P} \leq 0.01)$.

${ }_{1}^{1} \mathrm{~g} / 100 \mathrm{~g}$ live weight.

$2 \mathrm{~cm} / 100 \mathrm{~g}$ live weight. 
Birds in an area lined with wood shavings occasionally consumed litter by pecking and scratching, which may increase the efficiency of the dietary symbiotic supplement. Willis et al. (1997) reported that litter material consumed during the feed-withdrawal period was found in the intestinal tract of birds. Hetland and Svihus (2007) demonstrated that birds reared in wooden shavings floor consumed, on average, $4 \mathrm{~g}$ of litter material and showed a remarkable reduction of particle size of the digesta passing from the gizzard. In the current study, this might have occurred as well.

In addition, birds reared in an area floored with wood shavings may occasionally have had the dust-bathing behavior encouraged, which may improve animal welfare. Hetland and Svihus (2007) reported that dust-bathing materials affect nutrient digestion and gut physiology in birds reared on wood shavings. Similarly, Samli et al. (2010) reported that the high performance value of the group containing wood shavings may be due to the improvement of the level of animal welfare. Fouad et al. (2008) also reported that broilers grown in the litter system had higher weight gain compared with those grown in cages due to the improved welfare of the former. The increase in gastrointestinal system weight in the wood shavings + symbiotic supplementation group compared with control may be due to the larger surface area required for digestion, evidenced by the increased duodenal villi length and thickness in the wood shavings + symbiotic supplementation group. This may be an indicator of the development of the digestive system of the animals. Indeed, Baurhoo et al. (2009) reported that addition of $0.2 \%$ MOS to the diet did not affect growth performance, but increased digestion by increasing the duodenum, jejunum, and ileum villi length. Maintaining animals in cages instead of on the ground or using wood shavings in cages also confirmed these results.

\section{Conclusions}

The wood shaving litter system and the supplementation of a mixture of Saccharomyces cerevisiae, mannan oligosaccharides, and $\beta$-glucan improve the digestive tract of Japanese quail by improving their villi development and consequently their performance.

\section{Acknowledgments}

This study was conducted by using the Facilities of Agriculture Faculty of Ahi Evran University, Kırşehir, Turkey.

\section{References}

Ayasan, T. 2013. Effects of dietary inclusion of protexin (probiotic) on hatchability of Japanese quails. Indian Journal of Animal Science 83:78-81.

Baurhoo, B.; Ferket, P. R. and Zhao, X. 2009. Effects of diets containing different concentrations of mannanoligosaccharide or antibiotics on growth performance, intestinal development, cecal and litter microbial populations, and carcass parameters of broilers. Poultry Science 88:2262-2272.

Ceylan, N. and Ciftci, I. 2003. The effects of some alternative feed additives for antibiotic growth promoters on the performance and gut microflora of broiler chicks. Turkish Journal of Veterinary and Animal Sciences 27:727-733.

Erener, G.; Ocak, N.; Öztürk, E. and Özdaş, A. 2001. Ekmek mayası yan ürününün etlik piliçlerin performans ve bazı kesim özellikleri üzerine etkileri. Ankara Üniversitesi Ziraat Fakültesi Tarım Bilimleri Dergisi 7:106-111.

Fouad, M. A.; Razek, A. H. A. and Badawy, S. M. 2008. Broilers welfare and economics under two management alternatives on commercial scale. International Journal of Poultry Science 7:1167-1173.

Genc, M. A.; Yilmaz, E. and Genc, E. 2006. Yeme eklenen mannanoligosakkarit'in karabalıkların (clarias gariepinus (burchell, 1822)) gelişimine, barsak ve karaciğer histolojisine etkileri. Ege University, Journal of Fisheries \& Aquatic Sciences 23:37-41.

Hamasalim, H. J. 2016. Synbiotic as feed additives relating to animal health and performance. Advances in Microbiology 2016:288-302.

Hetland, H. and Svihus, B. 2007. Inclusion of dust bathing materials affects nutrient digestion and gut physiology of layers. Journal of Applied Poultry Research 16:22-26.

Karaoglu, M. and Durdag, H. 2005. The influence of dietary probiotic (Saccharomyces cerevisiae) supplementation and different slaughter age on the performance, slaughter and carcass properties of broilers. International Journal of Poultry Science 4:309-316.

Koc, F.; Samli, H.; Okur, A.; Ozduven, M.; Akyurek, H. and Senkoylu, N. 2010. Effects of Saccharomyces cerevisiae and/or mannanoligosaccharide on performance, blood parameters and intestinal microbiota of broiler chicks. Bulgarian Journal of Agricultural Science 16:643-650.

Markovicva, R.; Šefera, D.; Krsticvb, M. and Petrujkicv, B. 2009. Effect of different growth promoters on broiler performance and gut morphology. Archivos de Medicina Veterinaria 41:163-169.

Morales-López, R.; Auclair, E.; García, F.; Esteve-Garcia, E. and Brufau, J. 2009. Use of yeast cell walls; $\beta$-1, 3/1, 6-glucans; and mannoproteins in broiler chicken diets. Poultry Science 88:601-607.

Nikpiran, H.; Vahdatpour, T.; Babazadeh, D. and Vahdatpour, S. 2013. Effects of Saccharomyces cerevisiae, thepax and their combination on blood enzymes and performance of japanese quails (Coturnix japonica). Journal of Animal and Plant Sciences 23:369-375.

NRC - National Research Council. 1994. Nutrient requirements of poultry. 9th rev. ed. National Academy Press, Washington D.C.

Ozsoy, B. and Yalcin, S. 2011. The effects of dietary supplementation of yeast culture on performance, blood parameters and immune system in broiler turkeys. Ankara Üniv. Veteriner Fakültesi Dergisi 58:117-122.

Ozturk, E. and Yildirim, A. 2004. Prebiotics supplementation to the diets broiler on performance and intestinal microbiological characteristics. Ulusal Zootekni Bilim Kongresi, Cilt 2. 152-156, Isparta.

Samli, H. E.; Dezcan, S.; Koc, F., Ozduven, M. L.; Okur, A. A. and Senkoylu, N. 2010. Effects of Enterococcus faecium supplementation and floor type on performance, morphology of erythrocytes and intestinal microbiota in broiler chickens. British Poultry Science 51:564-568. 
Sekeroglu, A.; Eleroglu, H.; Sarica, M. and Camci, O. 2013. Yerde üretimde kullanılan altlık materyalleri ve altlık yönetimi. Tavukçuluk Araştırma Dergisi 10:25-34.

Willis, W. L.; Murray, C. and Talbott, C. 1997. Evaluation of leaves as a litter material. Poultry Science 76:1138-1140.

Xu, Z. R.; Hu, C. H.; Xia, M. S.; Zhan, X. A. and Wang, M. Q. 2003. Effects of dietary fructooligosaccharide on digestive enzyme activities, intestinal microflora and morphology of male broilers. Poultry Science 82:1030-1036.
Zhang, A, W.; Lee, B. D.; Lee, S. K.; Lee, K. W.; An, G. H.; Song, K. B. and Lee, C. H. 2005. Effects of yeast (Saccharomyces cerevisiae) cell components on growth performance, meat quality, and ileal mucosa development of broiler chicks. Poultry Science 84:1015-1021.

Zhang, B.; Guo, Y. and Wang, Z. 2008. The modulating effect of beta1, 3/1, 6-glucan supplementation in the diet on performance and immunological responses of broiler chickens. Asian-Australasian Journal of Animal Sciences 21:237-244. 